\title{
Effect of different prokinetic agents and a novel enterokinetic agent on postoperative ileus in rats
}

\author{
B Y De Winter, G E Boeckxstaens, J G De Man, T G Moreels, J A J Schuurkes,
} T L Peeters, A G Herman, P A Pelckmans

\begin{abstract}
BackgroundlAim-The effects of different prokinetic agents, the motilide erythromycin and the substituted benzamides metoclopramide and cisapride, were investigated in a rat model of postoperative ileus. These effects were compared with that of granisetron, a 5-hydroxytryptamine $\left(5-\mathrm{HT}_{3}\right)$ receptor antagonist, and a novel enterokinetic agent, prucalopride, a $5-\mathrm{HT}_{4}$ receptor agonist.
\end{abstract}

Methods-Different degrees of inhibition of gastrointestinal transit, measured by the migration of Evans blue, were achieved by skin incision, laparotomy, or laparotomy plus mechanical stimulation of the gut.

Results-Metoclopramide decreased the transit after laparotomy with or without mechanical stimulation, whereas cisapride increased it after all three operations. Granisetron had no effect on the transit after the three operations when given alone. Prucalopride tended to increase the transit after laparotomy with or without mechanical stimulation when given alone. However, statistical significance was only reached when prucalopride was combined with granisetron. Erythromycin, a motilin receptor agonist, did not improve postoperative ileus in the rat.

Conclusions-Cisapride, but not metoclopramide or erythromycin, is able to improve postoperative ileus in the rat. The results suggest that a combination of $5-\mathrm{HT}_{3}$ receptor antagonist and $\mathbf{5 - \mathrm { HT } _ { 4 }}$ receptor agonist properties may be required to obtain a beneficial effect on surgery induced ileus in the rat. Furthermore, they indirectly indicate that stimulation of the excitatory mechanisms is not able to overcome the inhibitory influence of the neural reflex pathways activated during abdominal surgery. (Gut 1999;45:713-718)

Keywords: ileus; motilin; cisapride; metoclopramide; 5- $\mathrm{HT}_{3}$ receptor; $5-\mathrm{HT}_{4}$ receptor

Substituted benzamides, such as metoclopramide and cisapride, are prokinetics which are often used to treat upper abdominal symptoms related to delayed gastric emptying. These agents possess 5-hydroxytryptamine $\left(5-\mathrm{HT}_{3}\right.$, serotonin) receptor antagonist and $5-\mathrm{HT}_{4}$ receptor agonist properties. ${ }^{12}$ Their antiemetic activity probably results from $5-\mathrm{HT}_{3}$ receptor antagonism. ${ }^{1-4}$ In addition, $5-\mathrm{HT}_{3}$ receptor antagonists are able to accelerate gastric emptying in some species such as the rat. ${ }^{56}$ Their prokinetic activity mainly results from 5- $\mathrm{HT}_{4}$ receptor agonism. ${ }^{1-4}$ The prokinetic benzamides probably enhance stomach motility in humans by enhancing cholinergic transmission possibly by stimulating neuronal 5- $\mathrm{HT}_{4}$ receptors. In the human colon, the benzamides cause relaxation of the circular colonic smooth muscles in vitro. Apparently in contrast, cisapride mildly stimulates lower gut motility and is moderately effective in the treatment of constipation. It is suggested that additional mechanisms may explain the effects of prokinetics on lower gut motility. ${ }^{2}$

$5-\mathrm{HT}_{4}$ receptor activation can cause relaxation or contraction depending on the region, cell type, and species under study. So far, our knowledge on the distribution and exact localisation of the $5-\mathrm{HT}_{4}$ receptors in humans is limited. In human tissues, the effects of selective $5-\mathrm{HT}_{4}$ receptor agonists suggest that these receptors are present on jejunal mucosa, ileal mucosa, gastric cholinergic neurones, and circular colonic muscles. ${ }^{1-3}$ In general, increased motor activity following $5-\mathrm{HT}_{4}$ receptor activation results from increased release of acetylcholine from cholinergic neurones, and relaxation results from activation of $5-\mathrm{HT}_{4}$ receptors on smooth muscle cells. ${ }^{7}$ In humans, mice, and dogs, selective $5-\mathrm{HT}_{4}$ receptor agonists have been shown to accelerate colonic transit. ${ }^{49}$ They initiate a peristaltic reflex in humans and guinea pigs. ${ }^{70}$ In the rat gastrointestinal tract, $5-\mathrm{HT}_{4}$ receptor agonists stimulate gastric emptying. ${ }^{2} 311$

Recently, a new 5- $\mathrm{HT}_{4}$ receptor agonist, prucalopride, was introduced. ${ }^{12}{ }^{13}$ It is the first representative of the novel class of benzofurans, and is a highly specific and selective $5-\mathrm{HT}_{4}$ receptor agonist. It has been shown to accelerate delayed gastric emptying and to induce giant migrating contractions in dogs. ${ }^{14}{ }^{15}$ It has also been shown to shorten orocaecal and whole gut transit time in humans. ${ }^{16}$ These enterokinetic properties may be of great importance for the treatment of motor disorders characterised by decreased motility.

Postoperative ileus is a common complication after abdominal surgery and is defined as inhibition of the propulsive intestinal motility. It is generally accepted to result from activation of inhibitory neural reflex pathways involving inhibitory adrenergic neurones. ${ }^{17}$ We have previously shown the involvement of adrenergic and nitrergic neurones in the pathogenesis of

Abbreviation used in this paper: $5-\mathrm{HT}$, 5-hydroxytryptamine. 
postoperative ileus in the rat: a combination of the adrenergic neurone blocking drug reserpine and the nitric oxide synthase inhibitor L-nitroarginine was able to completely reverse the inhibition of the transit induced by a laparotomy plus mechanical stimulation of the gut. ${ }^{18}$ In this study, we investigated whether stimulation of excitatory pathways could overcome these inhibitory reflex pathways and eventually resolve postoperative ileus. Therefore we evaluated the effect of the enterokinetic prucalopride and compared its action with that of the clinically used prokinetics cisapride and metoclopramide. We also compared its effect with that of erythromycin, the model compound for a new class of prokinetics, the motilides, which are at present under development. ${ }^{1}$ Cisapride is a more potent prokinetic agent than metoclopramide and is devoid of antidopaminergic activity. They both increase the release of acetylcholine from the postganglionic nerve endings in the myenteric plexus by activation of a neural 5- $\mathrm{HT}_{4}$ receptor. ${ }^{1920}$ Erythromycin, a macrolide antibiotic, has been shown to be a motilin receptor agonist. $^{21} 22$ Synthetic analogues of erythromycin, the motilides, are devoid of antibacterial properties and they represent a new class of prokinetic agents. ${ }^{1}$

\section{Materials and methods}

EXPERIMENTAL PROTOCOL

All procedures received approval from the commission for medical ethics at the University of Antwerp. Male Wistar rats (145-235 g) were fasted for 48 hours with free access to water. The operation protocol has previously been described in detail. ${ }^{18}$ Briefly, the rats were randomly divided into three groups and received an abdominal operation under ether anaesthesia. We have previously shown that ether anaesthesia has no effect on gastrointestinal transit in our rat model of ileus. ${ }^{18}$ In the first group, an abdominal skin incision was made after the abdomen had been shaved and disinfected. The second group had a laparotomy consisting of an incision through the abdominal skin, abdominal muscle layers, and peritoneum. The third group had a laparotomy followed by evisceration and mechanical stimulation of the small intestine and caecum. After the operations, the rats were allowed to recover for one hour. They then received an intragastric injection of $0.1 \mathrm{ml}$ Evans blue $(50 \mathrm{mg}$ in 1 $\mathrm{ml} 0.9 \% \mathrm{NaCl}^{23}$ through a specially designed orogastric cannula introduced through the mouth. After 20 minutes, the rats were killed under ether anaesthesia and intestinal transit was measured as the migration of Evans blue from the pylorus to the most distal point of migration and expressed as distance $(\mathrm{cm})$ migrated by the stain.

In a first series of experiments, the effect of two prokinetic agents, metoclopramide and cisapride, was tested on intestinal transit of Evans blue. The drugs were injected before the operation in an attempt to prevent development of postoperative ileus. The rats were randomly divided into three groups. The first group served as a control and received an intravenous injection of vehicle in a tail vein.
They then underwent a skin incision, laparotomy, or laparotomy plus mechanical stimulation. The second group received an intravenous injection of metoclopramide 30 $\mathrm{mg} / \mathrm{kg}$ one minute before the operation. The third group received an intravenous injection of cisapride $1 \mathrm{mg} / \mathrm{kg}$ one minute before the operation. The dose inducing $50 \%$ of the maximum effect $\left(\mathrm{ED}_{50}\right)$ for stimulation of gastric emptying in the rat has previously been shown to be $1-1.5 \mathrm{mg} / \mathrm{kg}$ for cisapride and approximately eight times higher for metoclopramide. ${ }^{524}$ However, in preliminary experiments, no prokinetic effect of metoclopramide $10 \mathrm{mg} / \mathrm{kg}$ could be demonstrated in control rats (data not shown), therefore we increased the dose to $30 \mathrm{mg} / \mathrm{kg}$.

In a second series of experiments, we tested the effect of the 5- $\mathrm{HT}_{3}$ receptor antagonist granisetron. The rats were divided randomly into three groups. Rats in the first group served as a control and were injected with vehicle one minute before the operation. The second group was injected intravenously with granisetron 10 $\mu \mathrm{g} / \mathrm{kg}$ and the third group with granisetron 50 $\mu \mathrm{g} / \mathrm{kg}$ one minute before the operation. The $\mathrm{ED}_{50}$ value for stimulation of gastric emptying in rats for granisetron is $10 \mu \mathrm{g} / \mathrm{kg} .^{5}$

In a third series of experiments, we tested the effect of the selective $5-\mathrm{HT}_{4}$ receptor agonist, prucalopride. $^{12}$ Prucalopride (R093877/ $\mathrm{R} 108512$ ) is a newly synthesised enterokinetic agent and a benzofuran derivative with the chemical structure 4-amino-5-chloro-2,3dihydro- $N$-[1 (3-methoxypropyl)-4-piperidinyl]7-benzofurancarboxamide monochloride. The rats were divided randomly into three groups. The first group received an intravenous injection of vehicle and served as a control. The second group was injected intravenously with prucalopride $1 \mathrm{mg} / \mathrm{kg}$ and the third group with prucalopride $5 \mathrm{mg} / \mathrm{kg}$ one minute before the operation. The dose of prucalopride was based on gastric emptying studies using a non-caloric meal in rats (data on file at Janssen Research Foundation, Beerse, Belgium).

In a fourth series of experiments, we tested the effect of a combination of the $5-\mathrm{HT}_{3}$ receptor antagonist and the 5- $\mathrm{HT}_{4}$ receptor agonist on intestinal transit in rats. The rats were divided randomly into two groups. Rats in the first group served as a control and were injected intravenously with vehicle. The second group received an intravenous injection of granisetron $50 \mu \mathrm{g} / \mathrm{kg}$ immediately followed by an intravenous injection of prucalopride 1 $\mathrm{mg} / \mathrm{kg}$ one minute before the operation.

In a fifth series of experiments, the effect of erythromycin, a motilin receptor agonist, ${ }^{21}$ was tested on intestinal transit of Evans blue. The rats were randomly divided into two groups. Rats in the first group served as a control and received an intravenous injection of vehicle in a tail vein. They then had a skin incision, laparotomy, or laparotomy plus mechanical stimulation. The second group received an intravenous injection of erythromycin $1 \mathrm{mg} / \mathrm{kg}$ one minute before the operation. This dose has 


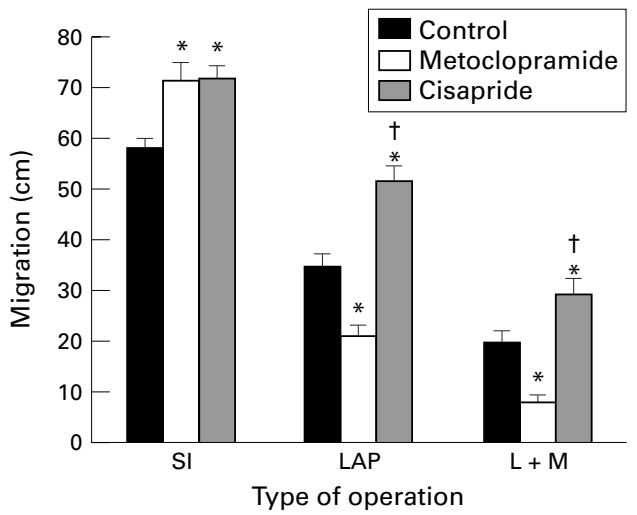

Figure 1 Effect of skin incision (SI), laparotomy (LAP), or laparotomy plus mechanical stimulation of the small intestine and caecum $(L+M)$ on intestinal transit in control rats $(n=9-10)$ and rats treated with metoclopramide $(30$ $\mathrm{mg} / \mathrm{kg} ; n=9)$ or cisapride $(1 \mathrm{mg} / \mathrm{kg} ; n=9-10)$. Results are expressed as $\mathrm{cm}$ migration of Evans blue and shown as mean (SEM). *Significantly different from the transit in control rats with the same operation $(p \leqslant 0.05)$;

tsignificantly different from the transit in rats treated with metoclopramide with the same operation $(p \leqslant 0.05)$ (one

way analysis of variance followed by the Bonferroni test).

previously been shown to induce a prokinetic effect in dogs, rabbits, and humans. ${ }^{25-27}$

CHEMICALS USED

The following chemicals were used: diethyl ether, L-ascorbic acid (Merck, Darmstadt, Germany), erythromycin lactobionate (Erythrocine; S A Abbott, Saint-Remy, France), Evans blue (Sigma, St Louis, Missouri, USA), granisetron hydrochloride (Kytril; Smithkline Beecham Pharma, Genval, Belgium), metoclopramide hydrochloride (Alpha Pharma, Zwevegem, Belgium), $\mathrm{NaCl} 0.9 \%$ (Plurule) and sterile water (Baxter, Lessines, Belgium). Granisetron was kindly provided by Dr J Dierckens (Smithkline Beecham Pharma). Cisapride (R051619) and prucalopride (R093877/R108512) were kindly provided by J $S$ (Janssen Research Foundation). Prucalopride was dissolved in sterile water, and cisapride was dissolved in $0.57 \mathrm{M}$ ascorbic acid. All other drugs were dissolved in $0.9 \%$ $\mathrm{NaCl}$.

PRESENTATION OF RESULTS AND STATISTICAL ANALYSIS

The total length of the small intestine was not statistically different between the groups (data not shown). Therefore results are expressed as distance $(\mathrm{cm})$ migrated by Evans blue. The measurements were made from the pylorus to the most distal point of migration. Group differences were assessed by simple factorial analysis of variance followed by unpaired Student's $t$ test or by one way analysis of variance followed by the Bonferroni test for multiple comparisons. Values are shown as mean (SEM). $\mathrm{p} \leqslant 0.05$ was considered to be significant. All data were analysed with the SPSS for windows software (SPSS Inc, Chicago, Illinois, USA).

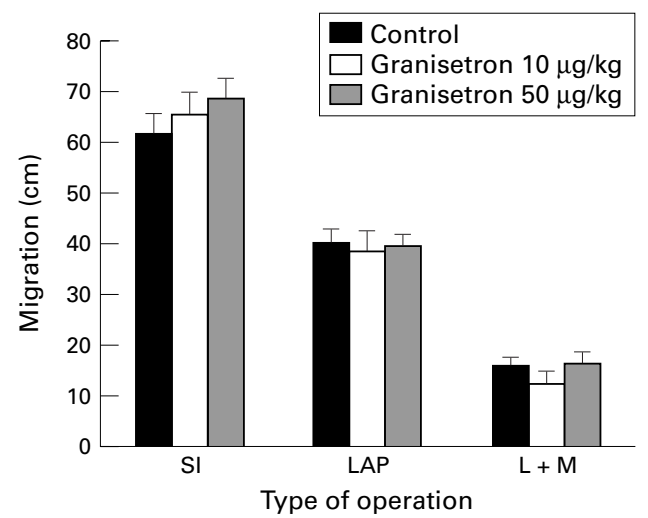

Figure 2 Effect of skin incision (SI), laparotomy (LAP), or laparotomy plus mechanical stimulation of the small intestine and caecum $(L+M)$ on intestinal transit in control rats $(n=9-10)$ and rats treated with granisetron $10 \mu \mathrm{g} / \mathrm{kg}$ $(n=9)$ or $50 \mu \mathrm{g} / \mathrm{kg}(n=9-10)$. Results are expressed as $\mathrm{cm}$ migration of Evans blue and shown as mean (SEM). One way analysis of variance could not detect any significant differences between the treatment groups.

\section{Results}

EFFECT OF METOCLOPRAMIDE AND CISAPRIDE ON INTESTINAL TRANSIT

In control rats, transit after skin incision was $57.8(2.1) \mathrm{cm}(\mathrm{n}=10)$. It was significantly decreased by laparotomy to $34.6(2.4) \mathrm{cm}(\mathrm{n}=$ 9). This inhibition of transit was even more pronounced after laparotomy plus mechanical stimulation $(19.4(2.4) \mathrm{cm}, \mathrm{n}=9$; fig 1$)$.

Metoclopramide $30 \mathrm{mg} / \mathrm{kg}$ significantly increased transit after skin incision from 57.8 $(2.1) \mathrm{cm}(\mathrm{n}=10)$ in control rats to 71.3 (3.5) $\mathrm{cm}(\mathrm{n}=9)$ (fig 1$)$. However, it further inhibited transit after laparotomy with or without mechanical stimulation: after laparotomy, transit was $20.8(2.4) \mathrm{cm}$ in rats treated with metoclopramide compared with $34.6(2.4) \mathrm{cm}$ in control rats, and after laparotomy plus mechanical stimulation, transit was $7.6(1.6) \mathrm{cm}$ in rats treated with metoclopramide compared with $19.4(2.4) \mathrm{cm}$ in control rats $(\mathrm{n}=9$, fig 1$)$.

Cisapride $1 \mathrm{mg} / \mathrm{kg}$ significantly increased transit after the three operations. It was 71.4 (2.6) $\mathrm{cm}(\mathrm{n}=9)$ after the skin incision, 51.6 (2.9) $\mathrm{cm}(\mathrm{n}=10)$ after laparotomy, and 28.9

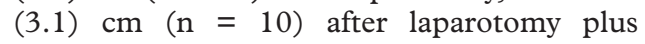
mechanical stimulation (fig 1).

The significant differences between the transit after skin incision and that after laparotomy with or without mechanical stimulation remained significant in the different treatment groups. Also the difference between transit after laparotomy and that after laparotomy plus mechanical stimulation remained significant in the three different groups.

EFFECT OF GRANISETRON ON INTESTINAL

TRANSIT

Granisetron had no effect on transit after the skin incision, laparotomy, or laparotomy plus mechanical stimulation. Transit after skin incision tended to increase but statistical significance was not reached: transit was $61.4(4.0)$ $\mathrm{cm}(\mathrm{n}=10)$ in control rats, $65.6(4.3) \mathrm{cm}(\mathrm{n}=$ 9) in rats treated with granisetron $10 \mu \mathrm{g} / \mathrm{kg}$, and $68.7(4.0) \mathrm{cm}(\mathrm{n}=10)$ in rats treated with granisetron $50 \mu \mathrm{g} / \mathrm{kg}$ (fig 2). Granisetron at a 


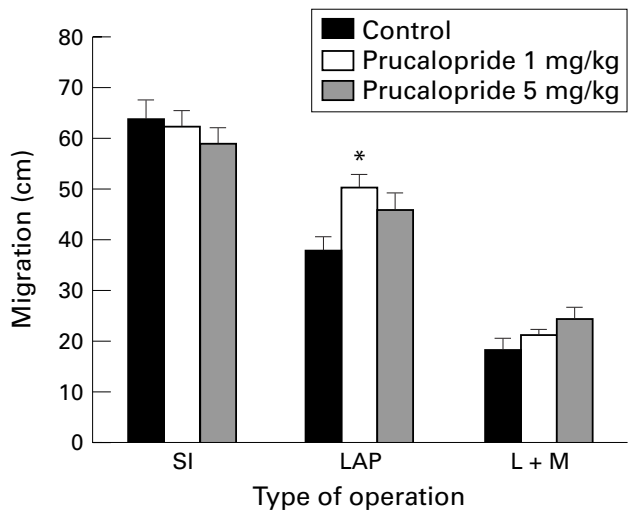

Figure 3 Effect of skin incision (SI), laparotomy (LAP), or laparotomy plus mechanical stimulation of the small intestine and caecum $(L+M)$ on intestinal transit in control rats $(n=9)$ and in rats treated with prucalopride $1 \mathrm{mg} / \mathrm{kg}$ $(n=9)$ or $5 \mathrm{mg} / \mathrm{kg}(n=9)$. Results are expressed as $\mathrm{cm}$ migration of Evans blue and shown as mean (SEM). *Significantly different from the transit in control rats after laparotomy $(p \leqslant 0.05)$ (one way analysis of variance followed by the Bonferroni test).

dose of either 10 or $50 \mu \mathrm{g} / \mathrm{kg}$ had no significant effect on transit after laparotomy or laparotomy plus mechanical stimulation ( $\mathrm{n}=9$, fig 2 ).

The differences between transit after the skin incision and that after laparotomy with or without mechanical stimulation, as well as the difference between transit after laparotomy alone and that after laparotomy plus mechanical stimulation remained significant in the different treatment groups.

EFFECT OF PRUCALOPRIDE ON INTESTINAL TRANSIT

Prucalopride had no effect on transit after the skin incision at either dose ( 1 and $5 \mathrm{mg} / \mathrm{kg}$ ) used. Transit was comparable with that $(63.6$ $(3.7) \mathrm{cm}$ ) in control rats after skin incision $(\mathrm{n}=$ 9, fig 3). Transit after laparotomy was significantly increased by prucalopride $1 \mathrm{mg} / \mathrm{kg}$ from $37.4(3.1) \mathrm{cm}$ in control rats to $49.9(2.8) \mathrm{cm}$ ( $\mathrm{n}=9$, fig 3 ). However, the increase produced by the $5 \mathrm{mg} / \mathrm{kg}$ dose was not significantly different: the transit was increased to 45.6 (3.4) $\mathrm{cm}(\mathrm{n}=9$, fig 3$)$. The transit after laparotomy plus mechanical stimulation tended to increase after treatment with prucalopride, but statistical significance was not reached. The transit was $17.9(2.4) \mathrm{cm}$ in control rats, $20.6(1.7) \mathrm{cm}$ after treatment with prucalopride $1 \mathrm{mg} / \mathrm{kg}$, and $23.9(2.5) \mathrm{cm}$ after treatment with prucalopride $5 \mathrm{mg} / \mathrm{kg}(\mathrm{n}=9$, fig 3 ).

The differences between the transit after skin incision and that after laparotomy with or without mechanical stimulation, as well as the difference between the transit after laparotomy alone and that after laparotomy plus mechanical stimulation remained significant in the different treatment groups.

EFFECT OF A COMBINATION OF GRANISETRON AND PRUCALOPRIDE ON INTESTINAL TRANSIT The combination of the $5-\mathrm{HT}_{3}$ receptor antagonist granisetron $(50 \mu \mathrm{g} / \mathrm{kg})$ and the $5-\mathrm{HT}_{4}$ receptor agonist prucalopride $(1 \mathrm{mg} / \mathrm{kg})$ had no effect on the transit after skin incision ( $\mathrm{n}=10$, fig 4). However, the transit after laparotomy was significantly increased from

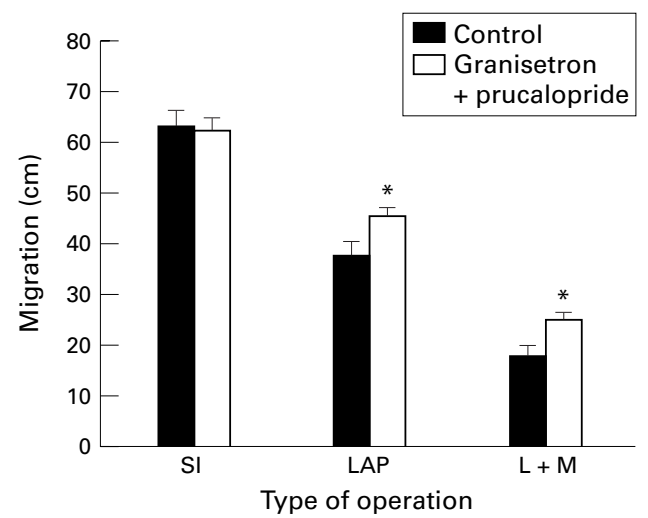

Figure 4 Effect of skin incision (SI), laparotomy (LAP), or laparotomy plus mechanical stimulation of the small intestine and caecum $(L+M)$ on intestinal transit in control rats $(n=10)$ and rats treated with a combination of granisetron $(50 \mu \mathrm{g} / \mathrm{kg})$ and prucalopride $(1 \mathrm{mg} / \mathrm{kg})(n=$ 9-10). Results are expressed as cm migration of Evans blue and shown as mean (SEM). *Significantly different from the transit in control rats with the same operation $(p \leqslant 0.05)$ (unpaired Student's t test).

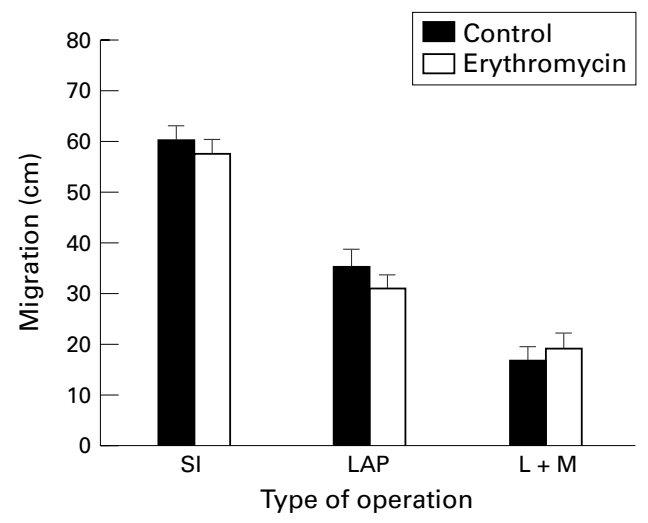

Figure 5 Effect of skin incision (SI), laparotomy (LAP), or laparotomy plus mechanical stimulation of the small intestine and caecum $(L+M)$ on intestinal transit in control rats $(n=9)$ and rats treated with erythromycin $(1 \mathrm{mg} / \mathrm{kg}$; $n=9)$. Results are expressed as cm migration of Evans blue and shown as mean (SEM). Unpaired Student's t test could not detect any significant differences between the treatment groups.

$37.5(2.8) \mathrm{cm}$ in control rats to $45.5(1.6) \mathrm{cm}$ (n $=10$, fig 4$)$. Transit after laparotomy plus mechanical stimulation was also significantly increased by this treatment from $17.4(2.2) \mathrm{cm}$ $(\mathrm{n}=10)$ in control rats to $24.6(1.8) \mathrm{cm}(\mathrm{n}=9)$ (fig 4).

In both groups, the differences between the transit after skin incision and that after laparotomy with or without mechanical stimulation and the difference between the transit after laparotomy alone and that after laparotomy plus mechanical stimulation remained significant, indicating that the combination treatment was not able completely to reverse the transit inhibition caused by the abdominal operations.

EFFECT OF ERYTHROMYCIN ON INTESTINAL TRANSIT

In control rats, transit after skin incision was 59.9 (3.0) cm. That after laparotomy was significantly decreased to $34.8(3.9) \mathrm{cm}$. This transit inhibition was even more pronounced when the laparotomy was associated with mechanical stimulation of the intestine (16.2 
(3.1) $\mathrm{cm}, \mathrm{n}=9$; fig 5). Erythromycin $1 \mathrm{mg} / \mathrm{kg}$ had no effect on the transit after the three operations ( $n=9$, fig 5 ).

The transit after the skin incision was significantly different from that after laparotomy with or without mechanical stimulation in both groups. Also the difference between the transit after laparotomy and that after laparotomy plus mechanical stimulation was significant in both groups.

\section{Discussion}

In our rat model of postoperative ileus, different degrees of inhibition of intestinal transit were achieved by different degrees of nociceptive stimulation. Skin incision had no effect on the transit, whereas it was significantly delayed by laparotomy. This inhibition was even more pronounced when the laparotomy was associated with mechanical stimulation of the gut, confirming earlier data obtained by Bueno et al. ${ }^{28}$ The role of inhibitory adrenergic neurones in the pathogenesis of postoperative ileus is generally accepted, ${ }^{17}$ but here we also show the involvement of inhibitory nitrergic neurones. ${ }^{18}$ In this study, we investigated the effect of prokinetic treatment on postoperative ileus in the rat. Although activation of $5-\mathrm{HT}_{4}$ receptors is believed to be the mechanism of action of substituted benzamides, ${ }^{12}$ the newly synthesised $5-\mathrm{HT}_{4}$ receptor agonist prucalopride did not improve recovery of postoperative ileus. Only combined $5-\mathrm{HT}_{4}$ receptor agonism and $5-\mathrm{HT}_{3}$ receptor antagonism, provided by either cisapride or a combination of granisetron and prucalopride, increased transit significantly after laparotomy with or without mechanical stimulation.

The selective 5- $\mathrm{HT}_{4}$ receptor agonist, prucalopride, ${ }^{12}{ }^{13}$ has been shown to induce giant migrating contractions and accelerate gastric emptying in dogs, and to stimulate gastrointestinal transit and bowel habits in healthy volunteers. ${ }^{14-16}$ However, in this study in the rat, prucalopride only tended to increase transit after laparotomy with or without mechanical stimulation, suggesting species differences. The effect of prucalopride is not clearly dose related, with only the lower dose significantly increasing transit after laparotomy. This lack of a dose related effect was also shown with other selective $5-\mathrm{HT}_{4}$ receptor agonists in a model of gastric emptying in the rat and $\operatorname{dog}^{11}$ and in a model of canine colonic transit. ${ }^{4}$ Hypothetically, the fact that prucalopride is a partial agonist may explain the different effects of cisapride and prucalopride. However, the lack of a dose related effect of prucalopride does not support this hypothesis. Granisetron, a 5- $\mathrm{HT}_{3}$ receptor antagonist, was not able to increase intestinal transit after the three operations when given alone, although it was used at a concentration equal to the $\mathrm{ED}_{50}$ value for gastric emptying in the rat. ${ }^{5}$ Whereas $5-\mathrm{HT}_{3}$ receptor antagonists were previously shown to increase gastric emptying in rats, ${ }^{56}$ in our study granisetron only tended to increase transit after skin incision, but statistical significance was not reached. In contrast, the combination of granisetron and prucalopride significantly increased transit after laparotomy with or without mechanical stimulation. Therefore we hypothesise that both $5-\mathrm{HT}_{3}$ receptor antagonism and $5-\mathrm{HT}_{4}$ receptor agonism are required to reduce experimental ileus in the rat. The effect of cisapride resembles that of the granisetron and prucalopride combination on transit after laparotomy with or without mechanical stimulation. As cisapride is known to possess both $5-\mathrm{HT}_{3}$ receptor antagonist and 5- $\mathrm{HT}_{4}$ receptor agonist properties, this finding may confirm our hypothesis. Several clinical studies have already shown a beneficial effect of repeated intravenous administration of cisapride on postoperative ileus, ${ }^{29-31}$ while other studies could not confirm this effect. ${ }^{32} 33$ Possibly, the effectiveness of cisapride in the resolution of postoperative ileus depends on the route of administration. ${ }^{34} \mathrm{~A}$ recent study in humans indicates that cisapride has prokinetic properties only when administered after the reappearance of the migrating motor complexes. ${ }^{35}$ In this study, cisapride was administered after the operation through a nasointestinal tube and it induced irregular spike bursts.

Interestingly, we found a differential effect of metoclopramide and cisapride on the abdominal surgery induced decrease in transit: metoclopramide further inhibited, whereas cisapride ameliorated the inhibition of, transit after laparotomy with or without mechanical stimulation. In a clinical randomised double blind study, Jepsen et $a l^{36}$ also demonstrated this unexpected negative effect of metoclopramide on postoperative ileus; they proposed that it was due to the generation of uncoordinated non-propulsive peristalsis. ${ }^{36}$ The difference between metoclopramide and cisapride could be related to different affinities for the $5-\mathrm{HT}_{3}$ receptor and the $5-\mathrm{HT}_{4}$ receptor or to the central dopamine antagonistic activity of metoclopramide that is lacking for cisapride. ${ }^{19}{ }^{20}$ On the other hand, recent reports suggest that cisapride enhanced gastroduodenal motility in the interdigestive state by increasing the plasma levels of motilin, ${ }^{37}$ suggesting that cisapride may enhance gastrointestinal motility by both serotonergic and non-serotonergic mechanisms. The latter may also explain the different effect of cisapride and the combination of prucalopride and granisetron on the transit after skin incision.

Erythromycin, a motilide, had no effect on transit in either normal conditions or after abdominal surgery. Similarly, Plourde et $a \beta^{8}$ could not show any improvement in gastric emptying in the rat after abdominal surgery even if the rats were treated with a higher concentration $(40 \mathrm{mg} / \mathrm{kg})$ of erythromycin. Although erythromycin induced an increase in the motility index of the small intestine in the rat in one study, ${ }^{39}$ several other studies failed to show a prokinetic action of erythromycin in the rat. $^{21}{ }^{22}$ These results may suggest that the rat is not an ideal species in which to study the effects of motilides, although motilin immunoreactivity has been shown in the rat small intestine. $^{22}$ In humans also, treatment with erythromycin did not alter the clinical variables 
of gastrointestinal motility after abdominal surgery, ${ }^{40}$ despite the acceleration of gastric emptying in healthy subjects ${ }^{41}$ and in patients with diabetic gastroparesis. ${ }^{42}{ }^{43}$ Therefore the efficacy of erythromycin or other motilides in the treatment of postoperative ileus remains to be proved.

In conclusion, of the prokinetics studied, only cisapride is of use in the treatment of postoperative ileus. Our study suggests that a combination of 5- $\mathrm{HT}_{3}$ receptor antagonist and $5-\mathrm{HT}_{4}$ receptor agonist properties may be required to obtain a beneficial effect on surgery induced ileus in the rat. Although prokinetics have a beneficial effect in the treatment of gastric emptying disorders, they may be of limited use in the treatment of postoperative ileus. Their clinical relevance remains to be proved. Our results indirectly indicate that stimulation of excitatory neurones is not able to overcome completely the inhibitory influence of the neural reflex pathways activated by abdominal surgery. However, it is worth investigating further the effects of novel enterokinetics that have profound effects on colonic motility in humans.

B De W is a research assistant of the Fund for Scientific Research-Flanders (FWO), Belgium. This work was supported by the FWO-Flanders, Belgium (grant no G.0220.96) ported by the FWO-Flanders, Belgium (grant no G.0220.96)
and by the Interuniversity Pole of Attraction Programme (grant and by the Interuniversity Pole of Attraction Programme (grant Scientific Technical and Cultural Affairs). The authors wish to thank Mrs L Van de Noort for typing the manuscript.

1 Tonini M. Recent advances in the pharmacology of gastrointestinal prokinetics. Pharmacol Res 1996;33:217-26.

2 Briejer MR, Akkermans LM, Schuurkes JAJ. Gastrointestinal prokinetic benzamides: the pharmacology underlying stimulation of motility. Pharmacol Rev 1995;47:63151.

3 Hegde SS, Wong AG, Perry MR, et al. 5-HT4 receptor mediated stimulation of gastric emptying in rats. Naunyn Schmiedebergs Arch Pharmacol 1995;351:589-95.

4 Nguyen A, Camilleri M, Kost LJ, et al. SDZ HTF 919 stimulates canine colonic motility and transit in vivo. $\mathcal{F}$ Pharmacol Exp Ther 1997;280:1270-6.

5 Ito $\mathrm{C}$, Isobe $\mathrm{Y}$, Tsuchida $\mathrm{K}$, et al. 5-Hydroxytryptamine(3) receptor and regulation of gastric emptying in rats. Arch Int Pharmacodyn Ther 1996;331:203-18.

6 Schiavone A, Volonte M, Micheletti R. The gastrointestinal motor effect of benzamide derivatives is unrelated to 5-HT3 receptor blockade. Eur F Pharmacol 1990;187:3235- 9 .$$
7 \text {. }
$$

Hegde SS, Eglen RM. Peripheral 5-HT4 receptors. FASEB F 1996;10:1398-407.

8 Appel S, Kumle A, Hubert M, et al. First pharmacokineticpharmacodynamic study in humans with a selective 5-hydroxytryptamine (4) receptor agonist. F Clin Pharmacol 1997;37:229-37.

9 Nagakura Y, Ito $\mathrm{H}$, Kiso $\mathrm{T}$, et al. The selective 5-hydroxytryptamine (5-HT)(4)-receptor agonis RS67506 enhances lower intestinal propulsion in mice. $尹$ pn f Pharmacol 1997;74:209-12.

10 Foxx-Orenstein AE, Kuemmerle JF, Grider JR. Distinct 5-HT receptors mediate the peristaltic reflex induced by mucosal stimuli in human and guinea pig intestine. Gastroenterology 1996;111:1281-90.

11 Garcia-Garayoa E, Monge A, Roca J, et al. VB20B7, a novel 5-HT-ergic agent with gastrokinetic activity. 2. Evaluation of the gastroprokinetic activity in rats and dogs. $\mathcal{F}$ Pharm Pharmacol 1997;49:66-73.

12 Briejer MR, Meulemans AL, Bosmans J-P, et al. In vitro pharmacology of the novel enterokinetic R093877 [abpharmacology of the novel enterokine

13 Briejer MR, Meulemans AL, Schuurkes JAJ. R093877, a specific and selective 5-HT4 receptor agonist. Neurogastroenterol Motil 1998;10:62.
14 Briejer MR, Meulemans AL, Wellens A, et al. R093877 dose-dependently accelerates delayed gastric emptying in
conscious dogs [abstract]. Gastroenterology 1997;112:A705.

15 Briejer MR, Meulemans AL, Van Daele P, et al. R093877 induces giant migrating contractions (GMC) and alters colonic motility patterns in awake dogs. Neurogastroenterol Motil 1998;10:62.

16 Emmanuel AV, Kamm MA, Roy AJ, et al. Effect of a novel prokinetic drug, R093877, on gastrointestinal transit in healthy voluntees. Gut 1998;42:511-16.

17 Livingston EH, Passaro EP. Postoperative ileus. Dig Dis Sci 1990;35:121-32.

18 De Winter BY, Boeckxstaens GE, De Man JG, et al. Effect of adrenergic and nitrergic blockade on experimental ileus in rats. Br 7 Pharmacol 1997;120:464-8.

19 Albibi R, McCallum RW. Metoclopramide: pharmacology and clinical application. Ann Intern Med 1983;98:86-95.

20 Dowling PM. Prokinetic drugs: metoclopramide and cisapride. Canadian Veterinary fournal 1995;36:115-16.

21 Peeters T, Matthijs G, Depoortere I, et al. Erythromycin is a motilin receptor agonist. Am f Physiol 1989;257:G470-4.

22 Itoh Z. Motilin and clinical application. Peptides 1997;18: 593-608

23 Tanila H, Kauppila T, Taira T. Inhibition of intestinal motility and reversal of postlaparotomy ileus by selective alpha 2-adrenergic drugs in the rat. Gastroenterology 1993;104: 2-adrenergi 24 .

24 Megens AAHP, Awouters FHL, Niemegeers CJE. General pharmacology of the four gastrointestinal motility stimuants bethanechol, metoclopramide, trimebutine, and cisapride. Arzneimittelforschung 1991;41:631-4.

25 Peeters TL. Erythromycin and other macrolides as prokinetic agents. Gastroenterology 1993;105:1886-99.

26 Peeters TL, Depoortere I. Motilin receptor: a model for development of prokinetics. Dig Dis Sci 1994;39:76S-78S.

27 Costa A, De Ponti F, Gibelli G, et al. In vivo characterization of the colonic prokinetic effect of erythromycin in the rabbit. Pharmacology 1997;54:64-75.

28 Bueno L, Ferre JP, Ruckebusch Y. Effects of anesthesia and surgical procedures on intestinal myoelectric activity in rats. Am 7 Dig Dis 1978;23:690-5.

29 Boghaert A, Haesaert G, Mourisse P, et al. Placebocontrolled trial of cisapride in postoperative ileus. Acta Anaesthesiol Belg 1987;38:195-9.

30 Verlinden M, Michiels G, Boghaert A, et al. Treatment of postoperative gastrointestinal atony. Br $\mathcal{F}$ Surg 1987;74: 614-17.

31 Tollesson PO, Cassuto J, Rimback G, et al. Treatment of postoperative paralytic ileus with cisapride. Scand f Gastroenterol 1991;26:477-82.

32 Hallerback B, Bergman B, Bong $\mathrm{H}$, et al. Cisapride in the treatment of post-operative ileus. Aliment Pharmacol Ther 1991;5:503-11.

33 Benson MJ, Roberts JP, Wingate DL, et al. Small bowel motility following major intra-abdominal surgery: the effects of opiates and rectal cisapride. Gastroenterology 1994;106:924-36.

34 Resnick J, Greenwald DA, Brandt LJ. Delayed gastric emptying and postoperative ileus after nongastric abdominal surgery: part II. Am f Gastroenterol 1997;92:934-40.

35 Shibata Y, Toyoda S. Effects of prostaglandin F $2 \alpha$ and cisapride on small intestinal activity during the early postoperative period in humans. Surg Today 1998;28:787-91.

36 Jepsen S, Klaerke A, Nielsen PH, et al. Negative effect of metoclopramide in postoperative adynamic ileus. A prospective, randomized, double blind study. $\mathrm{Br}$ f Surg 1986;73:290-1.

37 Song CW, Lee KY, Kim CD, et al. Effect of cisapride and renzapride on gastrointestinal motility and plasma motilin concentration in dogs. F Pharmacol Exp Ther 1997;281: concentration.

38 Plourde V, Trudel L, Poitras P. Motilin receptor stimulation and gastric postoperative ileus in rat [abstract]. Gastroenterology 1996;110:A736.

39 Pawlik WW, Gustaw P, Thor P, et al. Microcirculatory and motor effects of endogenous nitric oxide in the rat gut. $\mathcal{F}$ Physiol Pharmacol 1993;44:139-46.

40 Bonacini $M$, Quiason S, Reynolds $M$, et al. Effect of intravenous erythromycin on postoperative ileus. $A m \mathcal{F}$ Gastroenterol 1993;88:208-11.

41 Annese V, Janssens J, Vantrappen G, et al. Erythromycin accelerates gastric emptying by inducing antral contractions and improved gastroduodenal coordination. Gastroenterology 1992;102:823-8.

42 Janssens J, Peeters TL, Vantrappen G, et al. Improvement of gastric emptying in diabetic gastroparesis by erythromycin. N Engl f Med 1990;322:1028-31.

43 Minocha A, Katragadda R, Rahal PS, et al. Erythromycin shortens orocaecal transit time in diabetic male subjects: a double-blind placebo-controlled study. Aliment Pharmacol Ther 1995;9:529-33. 